\begin{tabular}{c} 
Volume and Issues Obtainable at Center for Sustainability Research and Consultancy \\
Journal of Accounting and Finance in Emerging Economies \\
ISSN: 2519-0318 ISSN (E) 2518-8488 \\
Volume 7: Issue 1 March 2021 \\
CSRC \\
Journal homepage: www.publishing.globalcsrc.org/jafee \\
\hline
\end{tabular}

\title{
What Drives Customer Loyalty in Islamic Banking? An Evidence from Pakistan
}

${ }^{1}$ Muhammad Umer Quddoos, ${ }^{2}$ Muhammad Asif Shamim, ${ }^{3}$ Muhammad Ramzan Sheikh,

\section{${ }^{4}$ Muhammad Tariq}

${ }^{1}$ Assistant Professor, Department of Commerce, Bahauddin Zakariya University Multan, Pakistan, umerattari@bzu.edu.pk

${ }^{2}$ Assistant Professor, Business Studies Department, Bahria Business School, Bahria University

Karachi Campus, Karachi, Pakistan, asifshamim.bukc@ bahria.edu.pk

${ }^{3}$ Associate Professor, School of Economics, Bahauddin Zakariya University Multan, Pakistan, ramzansheikh@bzu.edu.pk

${ }^{4}$ M.Phil. Scholar, Department of Statistics, Bahauddin Zakariya University, Multan, Pakistan, mtariqimsbzu@gmail.com

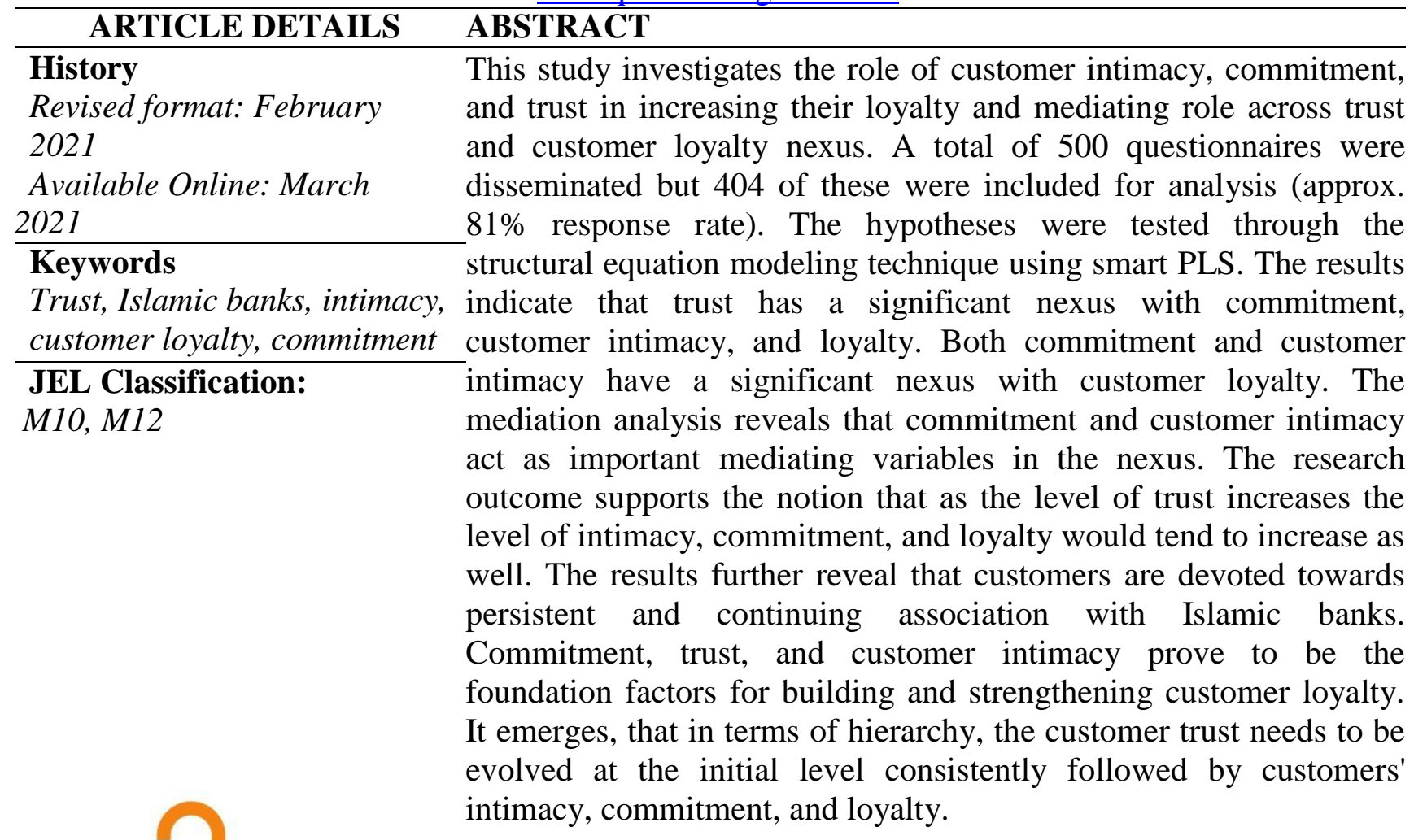

OPEN ACCESS

(C) 2020 The authors, under a Creative Commons AttributionNonCommercial 4.0

Corresponding author's email address: umerattari@bzu.edu.pk

Recommended citation: Quddoos, M. U., Shamim, M. A., Sheikh, M. R. \& Tariq, M. (2021). What Drives Customer Loyalty in Islamic Banking? An Evidence from Pakistan. Journal of Accounting and Finance in Emerging Economies, 7(1), 53-63 


\section{Introduction}

Currently, the competition of Islamic banks is not only with traditional banks but also with banks that have Islamic windows. These banks are facing competition in similar markets for offering savings and current accounts along with other services and products (Sumaedi et al., 2015). This rising competition amongst banking businesses to appeal the same clients is compelling Islamic banks to discover exclusive marketing tactics to improve and sustain association with their clientele. According to research, trust is regarded as one of the most imperative factors of collective associations between clients and banks. From the perspective of the Islamic banking system (IBS), trust refers to the client's belief about Islamic banking that it is functioning as per principles devised by Shariah (Amin et al., 2013). Trust turns out to be one of the most imperative features of the relationship between the Islamic bank and its client (Sumaedi et al., 2015). Available researches (e.g. Amin et al., 2013) have proposed numerous rewards due to belief in the system of Islamic banks and trust which ultimately provides assistance in dealings with clients and directs towards customer loyalty (Cust_loyl). The higher the level of the client's trust in the association, the higher will be his loyalty towards Islamic banks. Different studies found that commitment (Commt) (Fullerton, 2011) and customer intimacy (Cust_int) (Brock and Zhou, 2012) are suitable predictors in sustaining long-term relations with clients. Theoretically, in earlier studies the positioning of constructs i.e. (Cust_int) and (Commt) have been overlooked (Ashraf et al., 2015) in developing effective nexus between Islamic banks and their customers. However, here the researcher has tried to incorporate two major mediating concepts i.e. (Cust_int) and (Commt).

The idea was to analyze the effect of trust, (Commt) and (Cust_int) on the (Cust_loyl) in the context of Islamic banking along with the mediating effect of these variables i.e. (Commt) and (Cust_int) between trust and (Cust_loyl). There is still a dearth of study to explore how these variables perform as a mediating variable in the association between (Cust_loyl) and trust in Islamic banking particularly with respect to Pakistan. This research will help to gain a better insight into these variables with respect to Islamic banks in providing superior services, sustaining nexus with the customer, and achieving edge in the international market. Previous research (Khan et al., 2019) has highlighted that Commitment and trust are the key pillars for establishing loyalty.

\section{Literature Review}

\subsection{Trust}

Amongst all the vital constructs and variables involved in any business environment related to any product and service, trust has been given an utmost priority by available works of literature. (Robson et al., 2017). According to the trust can be defined as a virtue i.e. an outcome of confidence, sincerity, equity, fairness between humans and moral principles which are common to strengthen the service association between banks and customers. Considering this explanation, authors have divided trust into two different definitions that are benevolence and credibility. Credibility denotes to client's judgment about the (Commt) that has been made by a firm, and hence, trust is dependent on it. Whereas benevolence, on the other hand, refers to the client's trust that, corporation's aims and intents are helpful to them. In general, the level of truth will improve the cases of customers trusting a service provider or direct stakeholders, while the lack of trust will result the end of the relationship (Kabadayi, 2016; Jiang et al., 2015).

As per earlier studies, religious features are also considered as one of the main aspects when clients make their transactions with Islamic banks. For the financial sector, Ennew \& Sekhon (2007) describe trust as an association with accepting susceptibility, risk, dependence on each other, and positive concerns about potential activities. Haron et al., (1994) emphasized that customers in Malaysia have faith that religion is the only cause due to which they support the Islamic banks. According to Sumaedi et al. (2015), the trust of clients in Islamic banks vests in the adherence of Islamic banks to Islamic values. Kayed and Hassan (2011) also stressed that trust refers to the Islamicity of finance operations which have been recognized as the main source of trust-building between the banks (Amin et al., 2013). 


\subsection{Commitment}

Jones (2008) defined (Commt) as an emotional determination that emphasizes the linkage of an individual to a purpose. This concept also reflects the mental and emotional ties that are expected to have more benefits of staying in a partnership (Chenet, 2010). Sumaedi et al. (2015) emphasized in the context of Islamic banks that, the higher the affective (Commt) of clients, the higher will be the social connection between clients and their banks. Calculative (Commt) is the degree at which the exchange of information between each other is a need towards the maintenance of the relationship and to anticipate the cost of switching (Cater \& Zabkar, 2009). Aagja et al., (2011) found that if customers' perception is built towards the notion that the relationship will not be much profitable, this will direct the client towards switching of their bank. Some authors also present a rationale that in the context of Islamic banking clients are committed to Islamic banks because they are in a compulsion to do so (Sumaedi et al. 2015). Therefore, according to Thuy et al. (2016), it has been suggested by the authors that the discontinuation of the relationship between any company and their customers derives customer to a psychologically stressful and emotional phase where they tend to spend more of their efforts, time and money to explore alternatives.

\subsection{Customer Intimacy}

Brock and Zhou (2012) stated that (Cust_int) is the perception of the customer about having a mutual and very close association between buyers and suppliers. They further stated that the construct of (Cust_int) has been stated as multidimensional with the sub-constructs based on value perception, understanding of mutual side, and closeness. Closeness has been defined as the reflection of attributes associated with human behavior based on (Commt), affection, bonding, and empathy, which creates a strong sense of safety in a relation (Sirdeshmukh, 2002; Baumann and Le Meunier-FitzHugh, 2014). (Cust_int) has been further defined by two concepts: passion and (Commt) (Bügel, 2011). Though, the argument about customers and their nexus in terms of marketing have been presented by some researchers stating that intimacy is not just about revealing the truthfulness in terms of information a company has. It has also been highlighted that the relations in which self-disclosures are included are more intimate (Jacobs et al., 2001). Subsequently, it has been brought into light that the customers who share their confidential details with their respective suppliers develop intimate nexus. Overall bank performance is strongly dependent on the interpersonal nexus and the external relations of bank executives with the customer since the interaction has the direct impact of how a customer wants to continue their further contact with the relevant banks (Bügel, 2011; Balaji et al., 2016).

\subsection{Customer Loyalty}

In the field of marketing and business, (Cust_loyl) is one of the most discussed variables. Its impacts in different scenarios and various settings of businesses with respect to products and services have been discussed across diverse cultural contexts (Amin et al. 2013). The two main branches of loyalty are attitudinal and behavioral loyalty respectively. Attitudinal loyalty is expressed as the want of a customer-relevant to repurchase along with the willingness to recommend the purchases to further acquaintances. (Baumann et al., 2012; Hennig-Thurau, 2001; Wong \& Zhou, 2006). This kind of notion deals with the effectiveness of product purchases and the encouragement of the seller and can be used for businesses to design a better strategy based on relationship marketing (Oliver, 1999). Similarly, the concept of Behavioral loyalty refers simply to the affection of a customer towards a certain product and a repurchase that has been made against this affection. However, this notion of loyalty is unable to depict the loyalty in real terms since it has most factors which are related to certain objectives, though, it can predict the behavior of switching of product for customers. (Oliver, 1999). With respect to this research loyalty of customer can be stated as the behavior that a customer exhibit by continuing to stay committed and persistent while engaging with the bank for several new and old services offered. (Amin et al., 2013; Henrique \& Matos, 2015; Baumann et al., 2007; Zeithaml at el., 1996; Ladhari et al., 2011). Aluri et al., (2019) found that specious (Cust_loyl) is shifted easily in case of better choice or comfort in buying another brand. 


\section{Impact of Trust on Commitment}

Even if there is no agreement in the literature related to the association between trust and (Commt), it has been identified in several studies that trust contributes significantly to improving the (Commt) of customer (Čater and Čater, 2010; Shukla et al., 2016). According to Boateng and Narteh (2016), when clients and banks are engaged with each other, the clients must show trust in their bank before committing to them. Also, Gounaris (2005) emphasized that (Commt) will increase as trust increases. To the extent that Islamic banking is concerned, it was found in considerable studies that clients trust Islamic banks as their (Commt) to implement the belief is high. Non-significant relation was also found in numerous studies between (Commt) and trust (De Ruyter et al., 2001). Such as Cater and Zabkar (2009) specified the same non-significant relation because of a lack of options. Sumaedi et al. (2015) studied the influence of trust on (Commt) in the IBS and the outcomes showed no significant association between trust and (Commt), however, clients have trust in their banks. The reason might be the (Commt) of clients with different banks. So, according to the pieces of literature examined earlier it can be hypothesized that:

H1 = Trust has a significant effect on the (Commt) of customers associated with the IBS.

\subsection{Impact of Trust on Customer Intimacy}

Morgan and Hunt (1994) introduced the concept of trust in relationships related to services and acknowledged it as a significant aspect of building relationships (Yu et al., 2015). Further, Balaji et al., (2016) found that the development of (Cust_int) is the outcome of the client's trust in the provider of services. Ponder et al. (2016) debated that a client's readiness to intimate nexus with the provider of services is affected by the level of trust toward them. In the banking sector, (Cust_int) is comparatively high because of enhanced individual dealings between clients and personnel of banks (Chai et al., 2015). This specifies that effective nexus between clients and banks will be present when one of the parties is certain about the other party's integrity and dependability (Moorman et al., 1992; Mukherjee and Nath, 2007). Ashraf et al. (2015) debated that the more clients trust their Islamic banks, the more clients intimate their associations with Islamic banks. As a consequence, trust is anticipated to enhance (Cust_int). So, according to the literature examined earlier it can be hypothesized that:

$\mathbf{H 2}=$ Trust has a significant effect on the (Cust_int) of customers associated with the IBS.

\subsection{Impact of Trust on Customer Loyalty}

It has been examined through previous studies that trust is an essential parameter for creating relationship value (Ponder et al., 2016). Past studies showed that trust incorporates an important implication in setting up client loyalty. Kabadayi (2016) in his literature proposed the notion that an increase in customers' trust in their bank leads to a longer relationship for future transactions. Apparently, Cho \& Hu (2009), in their research claimed that loan transactions in the future and all the dealings with the banks are completely dependent on trust, and once it is achieved they will comfortably refer their banks to acquaintances. For IBSs, trust is recognized as a significant factor in the evolving loyalty of customers. Nevertheless, this behavior of customers is bound to demonstrate that the relationships in IBSs are exclusively created on the basis of Trust as the dealings and transactions are based on Shariah. (Tameme \& Asutay, 2012; Hassan \& Lewis, 2007). In this research, trust is expected to exhibit a direct impact with respect to client loyalty. So, according to the literature examined earlier it can be hypothesized that:

H3 = Trust has a significant and positive effect on the loyalty of clients associated with the IBS.

\subsection{Impact of Commitment on Customer Loyalty And Its Mediation Impact}

The impact of (Commt) on (Cust_loyl) has been examined by some scholars in B2C (Business to customer) nexus however according to Kwan Soo Shin et al., (2019) very few researchers have exhibited trust as the key predictor of loyalty by taking (Commt) as a mediator. Furinto (2009) considers monetary benefits that have been offered to the customers as the basis of increasing their loyalty and (Commt). It has also been proposed by some scholars i.e. (Garbarino \& Johnson, 1999; Rauyruen \& Miller, 2007) that intention to purchase in future or to keep up the relationship is due to (Commt) 
whereas it also results in readiness to recommend it to others (Hennig-Thurau et al., 2002; Chenet et al., 2010). In addition, the (Commt)-trust association theory Morgan and Hunt, (1994) also found that (Commt) is the integral mediating factor in creating any effective association. Cater and Zabkar (2009) emphasized that (Commt) is an appreciable mediating variable in for building and sustaining long term association. Likewise, Chenet et al. (2010) identified that (Commt) works as a mediating variable between trust, future intentions, and differentiation. Even, the influences of these relationships on the loyalty of customers have not been examined from the perspective of the IBS of Pakistan. So, according to the literature examined earlier it can be hypothesized that:

H4 = (Commt) has a significant effect on the (Cust_loyl) associated with Islamic Banks.

H5 = (Commt) mediates the relationship between trust and (Cust_loyl).

\subsection{Impact of (Cust_Int) on Customer Loyalty}

With respect to client intimacy, it has been examined that the relation between (Cust_int) and loyalty is found to be vital. Ponder et al., (2016) claimed that the level of customer trust which they exhibit towards the service providers influences customer's readiness to intimate the relationship with them. In the banking industry, due to the frequent personal interactions between the buyer and seller of services in an Islamic bank, the relationship i.e. intimacy is also relevantly high. (Chai, 2015; Bügel, 2011). According to Ashraf et al., (2015) clients intimate their nexus more with the IBS when they are loyal to their banks. Brock \& Zhou (2012) stated that the main source of (Cust_int) is the verbal and non-verbal interaction between the banks and the customers. In addition to the direct interactions between (Cust_int) and (Cust_loyl), the literature implies that (Cust_int) also performs the role of mediating variable between trust and (Cust_loyl). (Brock and Zhou, 2012). Even, the influences of these nexus on the loyalty of customers have not been examined from the perspective of the IBS of Pakistan. So, according to literature examined earlier it can be hypothesized that:

H6 = Intimacy of customers has a significant influence on the (Cust_loyl) associated with the IBS.

H7 = (Cust_int) mediates the nexus between (Cust_loyl) and trust.

\section{Research Methodology}

The questions of the instrument were adopted from different researches i.e. construct of trust consists of 4 items which were adopted from (Amin et al., 2013; Sumaedi, 2015), construct of (Commt) consists of 4 items which were adopted from (Brock \& Zhou, 2012; Sumaedi, 2015), the construct of intimacy consists of 5 items which were adopted from (Brock and Zhou, 2012) and finally construct of loyalty consists of 4 items which were adopted from (Zeithaml, 1996; Amin et al., 2013). Moreover, a five-point Likert scale from $1=$ Strongly disagree to $5=$ Strongly agree was utilized to assess each variable. A convenience sampling method was utilized in this study. The online survey was distributed among the class of individuals who have been clients of banks that offer Islamic banking services. As mentioned by Cohen, J. (1969) that the sample size needs to be greater than 384 in case if the population is above 1 million or unknown. Therefore, after disseminating around 500 questionnaires 404 were were returned with no missing values.

\section{Analysis of Data and Outcomes}

In order to assess the structural model PLS algorithm was run through software i.e. Smart PLS. For internal consistency, reliability was computed through Cronbach's $\alpha$ coefficient. The values that are shown in table I are above the threshold values i.e. as per (Hair et al., 2010) (CR) i.e. composite reliability, factor loadings, and (AVE) i.e. average variance extracted were applied to evaluate convergence validity. The suggested standards for loadings are specified at $>0.5$, CR ought to be $>0.7$ and the AVE needs to be $>0.5$ (Anderson and Gerbing, 1988). The results revealed that the value of the factor loading of each reflective indicator is between 0.709 and 0.868 . These values fulfill the criteria of threshold level i.e. 0.50 showing that the convergent validity for each variable was accomplished (Hair et al., 2012). Subsequently, AVE was calculated for each variable for evaluating discriminant validity as suggested by (Hair et al., 2010), and the values varied between 0.552 and 0.725 . Table II displayed the discriminant validity (Dis_Val) of the variable, as the AVE' square root between each set of the variable 
was greater than the correlation calculated between variables, thus its (Dis_Val) was conformed (Hair et al., 2010, 2012).

Table I. Factor Loadings, Alpha $\alpha$, CR and AVE Values

\begin{tabular}{|c|c|c|c|c|c|c|c|}
\hline & Commt & Cust_Int & Cust_loyl & Trust & $\alpha$ & CR & AVE \\
\hline Commt1 & 0.855 & & & & 0.812 & 0.888 & 0.725 \\
\hline Commt2 & 0.864 & & & & & & \\
\hline Commt3 & 0.835 & & & & & & \\
\hline Cust_Intm1 & & 0.717 & & & 0.797 & 0.860 & 0.552 \\
\hline Cust_Intm2 & & 0.752 & & & & & \\
\hline Cust_Intm3 & & 0.766 & & & & & \\
\hline Cust_Intm4 & & 0.768 & & & & & \\
\hline Cust_Intm5 & & 0.709 & & & & & \\
\hline Cust_loyl1 & & & 0.804 & & 0.854 & 0.901 & 0.695 \\
\hline Cust_loyl2 & & & 0.813 & & & & \\
\hline Cust_loyl3 & & & 0.848 & & & & \\
\hline Cust_loyl4 & & & 0.868 & & & & \\
\hline Trust1 & & & & 0.855 & 0.854 & 0.902 & 0.696 \\
\hline Trust2 & & & & 0.785 & & & \\
\hline Trust3 & & & & 0.859 & & & \\
\hline Trust4 & & & & 0.837 & & & \\
\hline
\end{tabular}

Table II. Discriminant Validity. (Fornell-Larcker Criterion)

\begin{tabular}{lllll}
\hline & Commt & Cust_int & Cust_loyl & Trust \\
\hline Commt & 0.852 & & & \\
Cust_Int & 0.714 & 0.743 & & \\
Cust_loyl & 0.656 & 0.743 & 0.834 & \\
Trust & 0.665 & 0.666 & 0.637 & 0.834 \\
\hline
\end{tabular}

HTMT ratio is used as a narrative measure for evaluating unique validity as proposed by Henseler et al. (2015) that all ratios shall be less than 0.90 . Table III demonstrates that all variables' values are less than 0.90 , and hence unique validity has been attained.

Table III. Heterotrait-Monotrait Ratio (HTMT)

\begin{tabular}{llll}
\hline & Commt & Cust_int & Cust_loyl \\
\hline Commt & & & \\
Cust_int & 0.878 & & \\
Cust_loyl & 0.782 & 0.896 & \\
Trust & 0.783 & 0.805 & 0.741 \\
\hline
\end{tabular}

\subsection{Path Analysis}

The assessment of the structural model under PLS was carried out by different tests including testing of hypotheses through the determination of path coefficient, the examination of R2, predictive relevance, determination of effect size, and goodness of fit. Empirical investigation determines the relationship among variables. After the initial examination as mentioned above, the significance and strength of the 
association between constructs were evaluated through path analysis. For path analysis, Bootstrapping through 5000 samples was applied (Preacher and Hayes, 2008) at a 5\% significance level.

Table IV Path Analysis

\begin{tabular}{llllllllll}
\hline Hypothesis & Paths & \multirow{2}{*}{ Estimate } & S.D & $\begin{array}{l}\text { T- } \\
\text { Stats }\end{array}$ & $\begin{array}{l}\text { P } \\
\text { Values }\end{array}$ & Result & $\begin{array}{l}\text { F- } \\
\text { Square }\end{array}$ & \multicolumn{2}{c}{$\begin{array}{l}\text { R- } \\
\text { Square }\end{array}$} \\
Square
\end{tabular}

Table IV depicts that all paths are significant i.e. $(\mathrm{p}<0.1)$, T-stats. $>1.96$, and $(\mathrm{p}<0.05)$ (Hair et al., 2013). This results in the acceptance of all alternative hypotheses. Figure1 shows the diagrammatic representation of the results of the model tested.

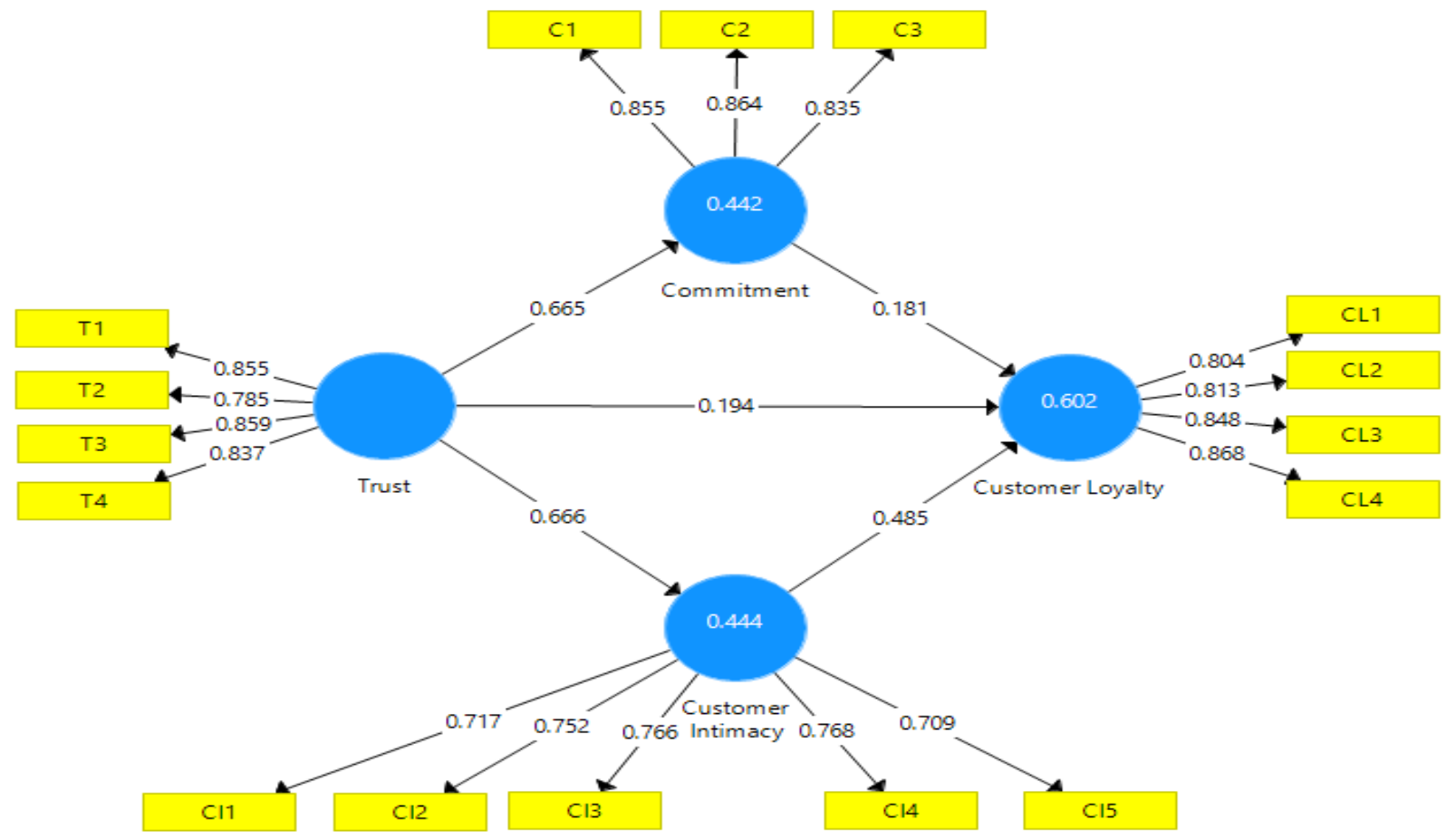

Figure 1:-Test Results of Research Model

H1 is supported by a significant positive link of trust and (Commt) of customers associated with IBS (an estimate of (0.665), $\mathrm{p}<0.05$, i.e. 0.00). Hence $\mathbf{H 1}$ is accepted.

H2 supported by a significant and positive link between trust and intimacy of customers associated with IBS (an estimate of (0.666), $\mathrm{p}<0.05$, i.e. 0.00). Hence $\mathbf{H 2}$ is accepted.

H3 supported by a significant and positive nexus between (Cust_loyl) and trust associated with Islamic banking. (an estimate of (0.194), $\mathrm{p}<0.05$, i.e. 0.00). Hence $\mathbf{H 3}$ is accepted.

H4 supported by a significant positive link between the (Commt) and loyalty of customers associated with the IBS. (an estimate of (0.181), p < 0.05, i.e. 0.00). Hence $\mathbf{H 4}$ is accepted.

H6 supported by a significant and positive link between intimacy and loyalty of customers associated with IBS with (estimate of (0.485), $\mathrm{p}<0.05$, i.e. 0.00). Hence H6 is accepted. 
The $\mathrm{Q}^{2}$ was analysed for the path model's predictive relevance. As suggested by Fornell and Cha (1993), the model is said to have prediction power if its value is greater than 0 , however, if the value is less than 0 then it is said that the model lacks prediction power. The $\mathrm{Q}^{2}$ values i.e. $0.295,0.392$, and 0.229 for (Commt), (Cust_loyl) and (Cust_int) are shown in Table IV showing that the path model contains predictive power for all three endogenous variables.

The value of $\mathrm{R}^{2}$ shows the predictive relevance of the model. The value of $\mathrm{R}^{2}$ needs to be greater than 0.10 (Falk \& Miller, 1992). Figure IV specifies that Trust predicts $44.2 \%$ of $(\mathrm{Commt})\left(\mathrm{R}^{2}=0.442\right)$, $44.4 \%$ of (Cust_int $)\left(\mathrm{R}^{2}=0.444\right)$ and $60.2 \%$ of (Cust_loyl $)\left(\mathrm{R}^{2}=0.602\right)$. These values show that $\mathrm{R}^{2}$ is significant and acceptable for the fitness of the PLS model. To check the effect size of variables, $\mathrm{F}^{2}$ was utilized. Recommended values for the magnitude of $\mathrm{F}^{2}$ as suggested by Cohen (1988) are small, medium, and large i.e. 0.10, 0.25, 0.35. The effect size of Trust on (Commt) and on (Cust_int) is 0.793 and 0.799 respectively having the $(\mathrm{P}=0.000)$, which infers quite large and significant effect. As far as the effect size of Trust on (Cust_int) is concerned it shows small effect i.e. 0.045 but with significant pvalue i.e. 0.000. In the case of (Commt) and Customer loyalty, the values are again small (0.0350 but significant $(\mathrm{p}=0.000)$ whereas for (Cust_int) and (Cust_loyl) it has a medium (0.251) and significant effect $(\mathrm{p}=0.000)$

\section{Table V Goodness of Fit}

\begin{tabular}{|c|c|c|}
\hline Variables & AVE & R Square \\
\hline Commt & 0.725 & 0.442 \\
\hline Cust_int & 0.552 & 0.444 \\
\hline Cust_loyl & 0.695 & 0.602 \\
\hline Trust & 0.696 & \\
\hline Average & 0.667 & 0.496 \\
\hline Gof $\sqrt{\operatorname{AVE}} \times R^{2}$ & 0.575293 & \\
\hline
\end{tabular}

The Goodness-of-fit (GoF) is suggested as a measure of fit for PLS path modeling and it shows the prediction power of the composite model. It ranges from 0 to 1. Though, for communality, Wetzels et al. (2009) recommended the following values i.e. small, medium, and large i.e. $0.10,0.25,0.35$. For this model, the value of Gof is 0.575 as shown in Table V and it satisfies the criteria for the large value of Gof for prediction power as mentioned above.

\subsection{Mediation Effect}

For testing the mediating effects of variables, (Commt), and (Cust_int), the approach for bootstrap proposed by Preacher and Hayes (2008) was adopted.

\section{Table VI Mediation Effect}

\begin{tabular}{lllll}
\hline & Estimate & S.D & T-Stats & P Values \\
\hline Trust $->$ Commt $->$ Cust_loyl & 0.121 & 0.033 & 3.693 & 0.000 \\
Trust $->$ Cust_int-> Cus_loyl & 0.323 & 0.039 & 8.233 & 0.000 \\
\hline
\end{tabular}

The mediating role of (Commt) and (Cust_int) in the nexus between trust and (Cust_loyl) is shown in Table VI. The outcomes show that both (Commt) and intimacy of customers are playing as partial mediating variables with (estimate of $(0.121), \mathrm{p}<0.05$, i.e. 0.00$)$ and (estimate of $(0.323), \mathrm{p}<0.05$, i.e. 0.00). Hence $\mathbf{H 5}$ and $\mathbf{H 7}$ are accepted.

\section{Discussion and Practical Implications}

The objective of this research was to examine the role of intimacy, commitment, and trust in increasing the loyalty of customers and to investigate the mediating role of customer intimacy and commitment in the association between customer loyalty and trust. The study outcome supports the proposition that as 
the level of trust increases, the level of intimacy (Balaji et al. 2016), commitment (Kwan Soo Shin et al., 2019) and loyalty of clients (Kwan Soo Shin et al., 2019) will also increase due to Sharia compliance of Islamic banks.

The outcome of mediation analysis indicates that commitment and customer intimacy partially mediate the association between trust and customer loyalty. These outcomes are new insights as full mediation effects have already been reported for commitment (e.g. Balaji., 2015; Kwan Soo Shin et al., 2019) and intimacy (Ponder et al., 2016). Initially, this research adds to the literary work by providing new insights regarding commitment, trust, customer loyalty and customer intimacy in Islamic banks. This research explains that trust performs a significant role in developing customer intimacy and commitment, which in turn affects the loyalty of the consumer. This procedure leads us to portray that trust supports in maintaining the association between clients and their respective banks. Evidently, clients relying upon their banks will probably establish commitment, and assessment of other alternative relations will be reduced to complement the loyalty of the consumer. Commitment, trust, and customer intimacy appear important in improving customer loyalty. To this stage, the additional trust of clients on their banks will result in additional engagement of the client in the customer loyalty procedure. This implies that trust needs to be evolved at the initial stage and then customer intimacy, commitment, and customer loyalty are consistently developed.

\section{References}

Aagja, J.P. Mammen, T., \& Amit. V. (2011). Validating Service Convenience Scale and Profiling Customers: A Study in the Indian Retail Context. The Journal for Decision Makers, 36(4): 25-49.

Aluri A, Price BS, McIntyre NH (2019). Using machine learning to cocreate value through dynamic customer engagement in a brand loyalty program. Journal of Hospitality \& Tourism Research, 43(1):78-100.

Amin, M., Isa, Z., \& Fontaine, R. (2013). Islamic Banks: Contrasting the Drivers of Customer Satisfaction on Image, Trust, and Loyalty of Muslim and Non-Muslim Customers in Malaysia. International Journal of Bank Marketing, 31, 79-97.

Anderson, J.C. and Gerbing, D.W. (1988), "Structural equation modelling in practice: a review and recommended two-step approach", Psychological Bulletin, 103 (3), 411-423.

Baumann, C., Burton, S., Elliott, G. and Kehr, H.M. (2007), "Prediction of attitude and behavioural intentions in retail banking", International Journal of Bank Marketing, 25 (2), 102-116.

Baumann, C., Hamin, H. and Tung, R.L. (2012), "Share of wallet in retail banking", International Journal of Bank Marketing, 30 (2), 88-101.

Baumann, J., \& Meunier-FitzHugh, K. Le. (2014). Trust as a facilitator of co-creation in customersalesperson interaction - an imperative for the realization of episodic and relational value? AMS Review, 4(1), 5-20.

Balaji, M. (2015), "Investing in customer loyalty: the moderating role of relational characteristics", Service Business, 9 (1), 17-40.

Balaji, M., Roy, S.K. and Wei, K.K. (2016), "Does relationship communication matter in B2C service relationships?”, Journal of Services Marketing, 30 (2), 186-200.

Boateng, S.L. and Narteh, B. (2016), "Online relationship marketing and affective customer commitment-the mediating role of trust”, Journal of Financial Services Marketing, 21 (2), 127-140.

Brock, J. K. U., \& Zhou, J. Y. (2012). Customer intimacy. Journal of Business and Industrial Marketing, 27(5), 370-383.

Bügel, M., Verhoef, P., \& P. Buunk, A. (2011). Customer intimacy and commitment to relationships with firms in five different sectors: Preliminary evidence. Journal of Retailing and Consumer Services, 18, 247-258.

Cater, Barbara, \& Zabkar, V. (2009). Antecedents and consequences of commitment in marketing research services: The client's perspective. Industrial Marketing Management, 38(7), 785- 797.

Čater, T., \& Čater, B. (2010). Product and relationship quality influence on customer commitment and loyalty in B2B manufacturing relationships. Industrial Marketing Management, 39, 1321- 
1333.

Chai, J.C.Y., Malhotra, N.K. and Dash, S. (2015), “The impact of relational bonding on intention and loyalty: the mediating role of the commitment foci in service relationships", Journal of Hospitality and Tourism Technology, 6 (3), 203-227.

Chenet, P., Dagger, T.S. and O'Sullivan, D. (2010), "Service quality, trust, commitment and service differentiation in business relationships", Journal of Services Marketing, 24 (5), 336-346.

Cho, J.E. and Hu, H. (2009), "The effect of service quality on trust and commitment varying across generations", International Journal of Consumer Studies, 33 (4), 468-476.

Cohen, J. (1969). Statistical power analysis for the behavioral Sciences. New York. Academic Press.

Cohen, J. (1988). Statistical Power Analysis for the Behavioural Sciences (2nd ed.). Hillsdale, New Jersey: Lawrence Erlbaum Associates.

De Ruyter, K., Moorman, L., \& Lemmink, J. (2001). Antecedents of Commitment and Trust in Customer-Supplier Relationships in High Technology Markets. Industrial Marketing Management, 30(3), 271-286.

Falk R. F. \& Miller, N. B. (1992) A Primer for Soft Modeling. Akron, Ohio: The University of Akron Press

Fornell, C., \& Cha, J. (1993). Partial Least Squares (PLS), Unpublished working paper. Ann Arbor: University of Michigan Business School.

Fullerton, G. (2003). When Does Commitment Lead to Loyalty? Journal of Service Research - J SERV RES, 5, 333-344.

Furinto, A., Pawitra, T. and Balqiah, T.E. (2009), "Designing competitive loyalty programs: how types of program affect customer equity", Journal of Targeting, Measurement and Analysis for Marketing, 17 (4), 307-319.

Garbarino, E., \& S. Johnson, M. (1999). The Different Roles of Satisfaction, Trust, and Commitment in Customer Relationships. Journal of Marketing, 63 (2), 70-87.

Gounaris, S. (2005). Trust and Commitment Influences on Customer Retention: Insights From Business-to-Business Services. Journal of Business Research, 58, 126-140.

Hair, J., Black, W.C., Babin, B.J. and Anderson, R.E. (2010), "Multivariate data analysis: a global perspective", Pearson Education, Inc., Upper Saddle River, NJ.

Hair, J.F., Sarstedt, M., Ringle, C.M. and Mena, J.A. (2012), "An assessment of the use of partial least squares structural equation modeling in marketing research", Journal of the Academy of Marketing Science, Vol. 40 No. 3, pp. 414-433.

Hair Jr, J. F., Hult, G. T. M., Ringle, C., \& Sarstedt, M. (2013). A primer on partial least squares structural equation modeling (PLS-SEM). Sage Publications.

Haron, S., Ahmad, N. and Planisek, S.L. (1994), "Bank patronage factors of Muslim and non-Muslim customers", International Journal of Bank Marketing, 12(1), 32-40.

Hennig-Thurau, T., Gwinner, K.P. and Gremler, D.D. (2002), "Understanding relationship marketing outcomes an integration of relational benefits and relationship quality", Journal of Service Research, 4 (3), 230-247.

Hennig-Thurau, T., Langer, M.F. and Hansen, U. (2001), "Modeling and managing student loyalty an approach based on the concept of relationship quality", Journal of Service Research, 3 (4) ,331-344.

Henrique, J.L. and Matos, C.A.d. (2015), "The influence of personal values and demographic variables on customer loyalty in the banking industry", International Journal of Bank Marketing, 33 (4), 571 587.

Henseler, J., Ringle, C. M., \& Sarstedt, M. (2015). A new criterion for assessing discriminant validity in variance-based structural equation modeling. Journal of the Academy of Marketing Science, 43(1), $115-135$.

Jacobs, R.S., Hyman, M.R. and McQuitty, S. (2001), "Exchange-specific self-disclosure, social selfdisclosure, and personal selling", Journal of Marketing Theory and Practice, 9 (1), 48-62.

Kabadayi, S. (2016). Customers' disatisfaction with banking channels and their intention to leave banks: The moderating effect of trust and trusting beliefs. Journal of Financial Services Marketing, 21(3), 194-208. 
Kayed, R.N. and Hassan, M.K. (2011), "The global financial crisis and Islamic finance”, Thunderbird International Business Review, 53(5), 551-564.

Khan I, Fatma M. Connecting the dots between CSR and brand loyalty: the mediating role of brand experience and brand trust. International Journal of Business Excellence. 2019;17(4):439-455.

Kwan Soo Shin, S., Amenuvor, F. E., Basilisco, R., \& Owusu-Antwi, K. (2019). Brand Trust and Brand Loyalty: A Moderation and Mediation Perspective. Current Journal of Applied Science and Technology, 1-17. https://doi.org/10.9734/cjast/2019/v38i430376

Ladhari, R., Souiden, N., \& Ladhari, I. (2011). Determinants of loyalty and recommendation: The role of perceived service quality, emotional satisfaction and image. Journal of Financial Services Marketing, 16(2), 111-124.

Morgan, R., \& Hunt, S. (1994). The Commitment-Trust Theory of Relationship Marketing. The Journal of Marketing, 58, 20-38.

Moorman, C., Zaltman, G., \& Deshpande, R. (1992). Relationships Between Providers and Usersof Market Research: The Dynamics of Trust Within and Between Organizations. Journal of Marketing Research, 29, 314-328.

Mukherjee, A. and Nath, P. (2007), "Role of electronic trust in online retailing: a re-examination of the commitment-trust theory", European Journal of Marketing, 41 (9/10), 1173-1202.

Oliver, R.L. (1999), “Whence consumer loyalty?”, The Journal of Marketing, 63, 33-44.

Ponder, N., Betsy, B.H. and Hansen, J.D. (2016), "The mediating effects of customers' intimacy perceptions on the trust-commitment relationship", Journal of Services Marketing, 30 (1), 75-87.

Preacher, K.J. and Hayes, A.F. (2008), "Asymptotic and resampling strategies for assessing and comparing indirect effects in multiple mediator models”, Behavior Research Methods, 40 (3), 879891.

Sirdeshmukh, D., Singh, J., \& Sabol, B. (2002). Consumer Trust, Value, and Loyalty in Relational Exchanges. The Journal of Marketing, 66, 15-37.

Shukla, P., Banerjee, M. and Singh, J. (2016), "Customer commitment to luxury brands: antecedents and consequences”, Journal of Business Research, 69 (1), 323-331.

Sumaedi, S., Juniarti, R.P. and Bakti, I.G.M.Y. (2015), "Understanding trust and commitment of individual saving customers in Islamic banking: the role of ego involvement", Journal of Islamic Marketing, 6 (3), 406-428.

Tameme, M., \& Asutay, M. (2012). An empirical inquiry into marketing Islamic mortgages in the UK. International Journal of Bank Marketing, 30, 150-167.

Thuy, P.N., Hau, L.N. and Evangelista, F. (2016), "Service value and switching barriers: a personal values perspective", The Service Industries Journal, 36 (3/4), 142-162.

Wong, A. and Zhou, L. (2006), "Determinants and outcomes of relationship quality: a conceptual model and empirical investigation", Journal of Int. Consumer Marketing. 18 (3), 81-105.

Yu, P.L., Balaji, M. and Khong, K.W. (2015), "Building trust in internet banking: a trustworthiness perspective", Industrial Management \& Data Systems, 115 (2), 235-252.

Zeithaml, V.A., Berry, L.L. and Parasuraman, A. (1996), "The behavioral consequences of service quality", The Journal of Marketing, 60 (2), 31-46. 